\title{
In Memoriam Igor Semenovich Kon (1928-2011)
}

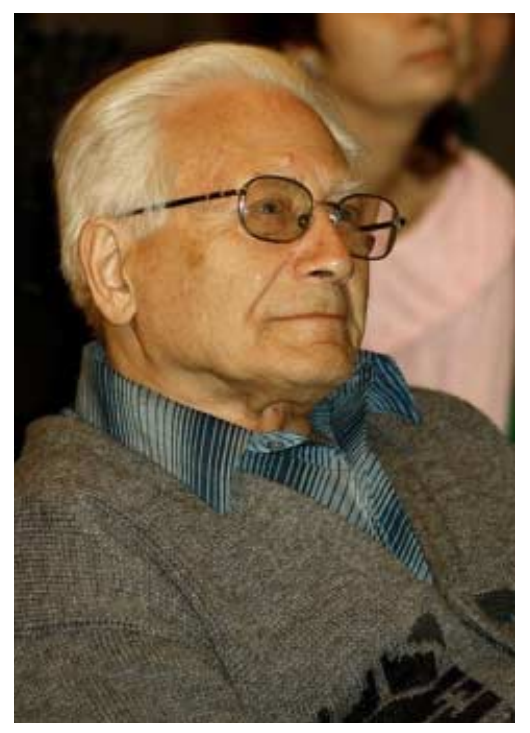

Igor Kon at the Annual meeting of the Institute of Ethnology and Anthropology of the Russian Academy of Sciences in January 2000 (picture taken by Natalia Pushkareva)
Igor Kon, a full member of the Russian Academy of Education and an outstanding Russian anthropologist, sociologist, psychologist, and teacher who opened up a series of new directions in each of these areas, including a gender perspective, unexpectedly died on 27 April 2011. He did not show his illness, remaining youthful looking until the end. A shining example of openness to all that was new and to personal freedom, he was modest, unbelievably self-sufficient, and able to explain the advantages of such a life choice. Igor Kon wrote about his life, full of difficulties, and the history of his overcoming them, in his autobiography 80 let odinochestva (Eighty years of solitude), ${ }^{1}$ published in 2008, which became an instant best seller in Russia. It was read not only by members of his generation but also by young people.

Born in Leningrad on 21 May 1928, half of his life was connected to the city on the Neva. There, he, along with his mother, survived the blockade during World War II. In those difficult and hungry post-war years he finished high school at the age of fifteen (in his last school years he also studied on his own, using dictionaries to learn several foreign languages). He was admitted to the history department of Herzen State Teachers' College in Leningrad. Gifted and preternaturally focused, he won permission to freely attend classes, and in 1947, at age nineteen, he completed his BA and went on to graduate study. At the age of 22 he brilliantly defended two dissertations simultaneously-one in history and one in philosophy. The authorities did not give him a chance to defend a third dissertation, saying: "Young man, there is no need to collect degrees!"2

Finishing up his three years of assigned work as a "young specialist in far-off Vologda," Kon returned home to Leningrad, where finding a job with an obviously 
Jewish last name and no membership in the Communist Party was not easy. The obvious "specialness" of the young teacher also raised hackles. Nevertheless, in the year following his return from Vologda, Kon succeeded in obtaining a position as docent at Leningrad State University, and to continue his studies in philosophy. Simultaneously with his teaching he worked hard on a new philosophical topic and in 1956, during the wave of a new social renewal and the easing of state anti-Semitism, he completed his doctoral dissertation, "Filosofskii idealism i krizis burzhuaznoi istoricheskoi mysli" (Philosophical idealism and the crisis of bourgeois historical thought), which he defended in 1959.

That year he turned 31. Together with his departmental colleagues, the young professor got involved in revitalizing Russian sociology - in the beginning in the form of empirical social research. In 1967 by his own estimation, his most important workthe book Sotsiologiia lichnosti (The sociology of personality) ${ }^{3}$-appeared. The book discussed the basic shortcomings of contemporary Russian society. Surrounded often by cowards or indifferent colleagues, repeatedly subject to injustice, Igor Kon tried to find and describe a fully realized society, with actively engaged individuals. The Sociology of Personality was translated into many foreign languages, a crowd of young people surrounded Kon at his lectures and speeches - not only in Russia, but in universities and laboratories around the world. By the end of the 1970s, I.S. Kon was already a genuine intellectual star.

The "tightening of the screws" after Khrushchev's "Thaw" in the Soviet Union finally put an end to all his illusions regarding the evolution of a Soviet type of socialism. This forced Kon to avoid politically dangerous subjects and focus on psychological themes, resulting in such books as Otkrytie Ia (Discovering the I, 1978) and V poiskakh sebia (In search of self, 1984), many articles about youth, friendship, the psychology of prejudice, the relationship of intellectuals to power, the dialectic of the development of nations, national character, and the features of national psychologies.

Kon did not separate his scientific-popularizing activity from his scholarship. He wrote each of his articles and books so that anyone could read them, and each of his publications really elicited a burst of interest. Journals with his articles were read until they were in tatters, and his books barely remained on the shelves of libraries, often checked out and not returned or simply disappearing completely. Not only in Leningrad, his hometown, not only in the capital, but - and especially! - in Russian regional universities, his name was on everyone's lips. ${ }^{4}$

He was an Enlightener in the highest sense of the word, an Enlightenment-Encyclopedist. Kon's knowledge in all areas of the humanities was unbelievable for those with whom he had personal contact. Continuing to work on different topics within the fields of social psychology, sociology, and philosophy, Kon in 1975 became a senior researcher in the General Problems Section of the Institute of Ethnography (now the Institute of Ethnology and Anthropology) of the Russian Academy of Sciences, beginning in the Leningrad branch of the institute. Thus, in the last thirty-five years of his life he was officially a social anthropologist.

In 1985 Igor Kon left Leningrad and moved permanently to Moscow. The idea of the elaboration of a, for Soviet scholarship new, subdiscipline of cultural anthropology - the history and ethnography of childhood - was realized in the form of a series 
of collective publications about the characteristics of the perception of childhood and their upbringing in the cultures of the world, and also in his monograph Rebenok $i$ obshchestvo (The child and society), first published in 1988, and reissued in a revised edition in 2003. ${ }^{5}$ The comparative historical study of developmental categories, gender-developmental symbolism, the particularities of the culture of childhood and the process of socialization of children in different human societies had not only theoretical but also important practical significance. I.S. Kon was the first to familiarize Soviet scholars with the conceptions of childhood of Philippe Aries and L. Demos, with statistical cross-cultural research, and in 1988 published a collection of the work of Margaret Mead, Kul'tura i mir detstva (The culture and world of childhood). ${ }^{6}$

At the end of the 1980s and the beginning of the 1990s, he was a visiting lecturer at many universities and research centers in Western Europe and the United States. In 1989, he was chosen a full member of the Academy of Educational Studies (now the Russian Academy of Education [RAO]) in the psychology section, and, at the same time, in a competitive process, he became a scholar at the Institute of Ethnology and Anthropology of the Russian Academy of Sciences. It was in those years that he focused on a new topic: the cultural anthropological study of sexual culture. Few of his colleagues and friends understood and accepted such a complete turn in the sphere of his scholarly interests and ambitions. The empirical study of the sexual behavior of adolescents, and the desire to enhance the popularization of sexual knowledge again brought his work to the attention of hundreds of thousands of ordinary readers. Indeed, the circulation of such books as Vvedenie k seksologiiu (Introduction to sexology, 1988), Vkus zapretnogo ploda (The taste of forbidden fruit, 1992), and Klubnichka na berezke. Seksual'naia kul'tura $v$ Rossii (The strawberry on the birch. Sexual culture in Russia, 1997) numbered in the millions. At the same time, his interest in such topics curtailed the number of his close academic friends; he began slowly to distance himself from the academic elite in our country and to be seen as an "alien" among sociologists and philosophers.

The dawning of the new millennium became for Kon a time for the search for new topics and untrodden tropes in scholarship. He already was a member of many international scientific societies, editorial collectives, and editorial boards. It is sufficient to note the most significant and central here-the International Sociological Association, the International Academy of Sexological Research, the European Association of Experimental Social Psychology, the German Society of Sexological Research, the Polish Academy of Sex Research, the Deutsche Gesellschaft fur Sexualforschung, the Professional Association of Russian Anthropologists, and the Moscow-Petersburg Philosophical Club. A list of all the editorial boards of journals of which he was a member and to whose pages he regularly contributed is also impressive: Human, Gender Studies, Andrology and Genital Surgery, Archives of Sexual Behavior, Zeitschrift für Sexualforschung, Journal of Homosexuality, Journal of the History of Sexuality, Childhood, Current Sociology, Sexualities, Men and Masculinities, among others.

The honor he most prized was the Gold Medal for "Outstanding Contributions to Sexology and Sexual Health," awarded to him by the World Sexological Association. He also received many other honors, including a visiting professorship at Cornell University (1989), an honorary doctorate from the University of Surrey (1992), and a 
medal for "Service to the Fatherland" awarded by the Russian government shortly before Kon's death.

Together with recognizing and strengthening the direction of gender studies in sociology, psychology, history, and cultural anthropology (he thought about strategies for preserving this field within Russian humanities in the last months of his life, and it was the subject of his last interview, broadcast on the radio and also published), he was also among the first in Russia to focus on masculinity studies. His last books - Lunnyi svet na zare. Liki i maski odnopoloi liubvi (Moonlight at dawn. Images and masks of samesex love, 1998), Liubov' nebesnogo tsveta, (Love the color of the sky, 2001), Muzhskoe telo $v$ istorii kul'tury (The male body in the history of culture, 2003), Muzhchina $v$ meniaiushchemsia mire (The male in a changing world, 2009), and Mal'chik-otets muzhchiny (The boy - father of the man, 2009) - showed the significance of a separate and special study of the male in culture. Supported by data from historical anthropology, evolutionary psychology, gender studies, and the social history of childhood, he studied the trans-historical and cross-cultural constants of boyhood as a global socio-cultural project and as well as its transformations in the modern and contemporary periods.

He studied homosexuality and was not afraid to write of the "differently loving" (inakoliubiashchikh), as he called them, stating that homosexuality was not a sickness, but a difference, although official science claimed the opposite. He was criticized, barred from publishing books. But he was not cowed, was firm in holding to his beliefs. Surveying various theories of homosexuality, the history and ethnography of same-sex relations among the peoples of the world, their problems, he determinedly spoke out for the decriminalization and depathologization of homosexuals. Speaking about the history and the position of the "differently loving" in Russia, he was also among the first in the country to raise the topic of the sexual abuse of children and the struggle against pedophilia.

Igor Semenovich Kon responded coolly - at least outwardly - to the fake bombs put under his front door, to the threats directed against him. He told about how fascist youth had organized a public protest against his works and disrupted an event at which he spoke. To the hecklers' taunts, he calmly replied, "You do not frighten us." The study of the history of the sexual counter-revolution of the early 2000s was, in his opinion, worthy of academic study and as useful as the history of Soviet sexology from 1930 to the 1980s.

He signed joint petitions in defense of or against all manner of issues, in solidarity with wise ideas and decent people. He sharply and uncompromisingly spoke out against the clericalization of education and academic knowledge, ${ }^{7}$ against conservatism and stagnation, for this was his ethics in practice.

During sixty years of scholarly work (his first small book was published in 1951, his last will appear after his death, towards the end of 2011) Igor Kon published twentyfive serious monographs. He instructed that after his death no memorial services be organized, but that his ashes be thrown to the winds. "People live as long as they are remembered," he said many times. Through his essays, articles, and monographs, his devotion to knowledge and to the idea of personal freedom and independent creativity, he remains with us, continuing to shine as an exemplary scholar and citizen. 


\section{Natalia Pushkareva}

\section{Translated by Rochelle G. Ruthchild}

\section{$\diamond$ Notes}

1. I.S. Kon, 80 let odinochestva (Eighty years of solitude) (Moscow: Vremia, 2008).

2. From the reminiscences of Appolon Davidson, Igor Kon's closest friend, who knew Kon since he was 14. See A.B. Davidson, Ob Igore nado pomnit' $i$ eto (This too we should remember about Igor), Demoskop-Weekly, nos. 465-466, 2-22 May 2011, http://www.demoscope.ru/weekly/ 2011/0465no. No/nauka01.php 5 (accessed 15 June 2011).

3. I.S. Kon, Sotsiologiia lichnosti (The sociology of personality) (Moscow: Politizdat, 1967).

4. There is no complete bibliography of Kon's works, but a list of his most important monographs is available at http://www.igorkon.ru/biografy/80\%20let\%2028.php (accessed 15 June 2011).

5. I.S. Kon, Rebenok i obshchestvo (The child and society) (Moscow: Nauka, 1988).

6. Margaret Mead, Kul'tura i mir detstva (Culture and the World of Childhood) (Moscow: Nauka, 1988).

7. Translator's Note: Here Pushkareva refers to the inclusion of religious texts in the school curriculum, inviting Russian Orthodox priests to propagandize in schools, promoting Churchfavored proposals for uni-sex schools and the creation of special finishing schools for girls, for the inculcation of "morality," and the intertwining of Russian history with that of the Russian Orthodox Church. 